\title{
The Perception, Incidence and Management of Sexual Harassment at Workplace: A Malaysian Case
}

\author{
SABITHA BAGAM MARICAN \\ School of Social Development \\ Universiti Utara Malaysia
}

\begin{abstract}
This paper focuses on perception and management of sexual harassment (SH) at the workplace. The study was carried out in Northern Malaysia among 586 public sector administrators. Results showed that $43 \%$ of the total male respondents and $47 \%$ of the female respondents have faced some kind of sexual harassment. Findings showed that the internal whistleblowing mechanism is also inadequate, though the respondents are quite confident with the management in reporting SH cases. Finally, the article outline strategies that could ameliorate the occurrence of SH at the workplace as it is important to the organization and the priceless workers in the organization.
\end{abstract}

\begin{abstract}
ABSTRAK
Kertas ini memfokus pada persepsi dan pengurusan gangguan seksual di tempat kerja. Kajian ini telah di jalankan di utara Malaysia di kalangan 586 pentadbir awam. Hasil kajian menunjukkan bahawa 43\% dari keseluruhan responden lelaki dan 47\% dari keseluruhan responden wanita pernah mengalami gangguan seksual sepertimana yang digariskan dalam soal selidik USHPQ. Hasil kajian juga menunjukkan bahawa mekanisme aduan tidak mencukupi, namun responden berasa agak yakin untuk untuk melaporkan kes gangguan seksual pada pihak pengurusan. Akhir sekali artikel ini menggariskan strategi-strategi yang boleh mengurangkan kejadian gangguan seksual di tempat kerja, kerana ia penting untuk organisasi dan pekerjanya yang tidak ternilai.
\end{abstract}

\section{INTRODUCTION}

\section{What is Sexual Harassment}

Sexual harassment impacts people and it impacts the organisation's bottom line. Thus when dealing with such issues a working definition is an important prerequisite to both the construction of a policy, and the investigative process. For sexual harassment to cease, some changes must take place. Before any changes can take place, however, a consistency of perceptions of sexual harassment needs to be attained. Thus, this establishes the need for a clear distinction to be drawn between a relation based on consent, and one where behaviour of a sexual nature is unwanted, unwelcome and unsolicited. Based on this formula four types of harassing behaviour can be identified (Fenley, 1988), those of physical nature (e.g. rape assault, touching grabbing, brushing), those of both verbal (e.g. persistent un- 
welcome sexual advances, request for sexual favors, and remarks, innuendoes, repeated request for unwanted dates, propositions, intrusive questions about private life), and non-verbal nature (e.g. whistling, rude gestures, leering, exposure) and those that are visual (e.g. displaying or circulating offensive literature, materials, or items).

The different types of behaviour discussed above need to be placed in context, especially with regard to the creation, continuation, and termination of the employment relationship. In Malaysia sexual harassment is also seen in accordance with the two main legal criteria that have been developed in the United States (Fenley, 1988). The first looks at harassing behavior in purely contractual terms sometimes called quid pro $q u o$ harassment. It means that in order to obtain a job, win promotion, or gain access to training opportunities or other benefits the granting of sexual favors becomes a contractual term, either explicitly or implicitly. Failure to comply may lead to non-employment, denial of training and promotional opportunities, demotion, poor work assignments or dismissal.

The second relates to the creation of a hostile working environment, where there may be no direct contractual dimensions involved. It is where there may be no clear contractual gain or penalty, but where a pattern of behaviour based on sex develops and creates an uncomfortable and hostile work situation for the victim. Such behaviour has the purpose or effect of unreasonably interfering with a person's performance on the job or creating an intimidating, hostile or offensive working environment.

As to why it happens, to date, there are three possible explanations offered by Tangri, Burt and Johnson (1982). The first possibility is that sexual harassment occurs because of a innate biological drive for men to be sexually aggressive. The second explanation has to do with organisational hierarchies where men hold ordinate positions. Last but not least is due to the 'sociocultural model' concludes that sexual harassment is a manifestation of a larger society in which men use harassment as a means to intimidate women (Pryor et al., 1993).

\section{Why it is a Serious Problem}

Sexual harassment is a serious problem in the workplace (Sheffey \& Tindale, 1992). Not only is it a problem that has an impact on individuals (Bingham \& Schere,1993), it also is a problem that can affect organizations both directly and indirectly (Fitzgerald \& Shullman, 1993). Legal costs incurred can be large when sexual harassment is not dealt with effectively (Bennet-Alexander \& Pincus, 1995). Furthermore, unwanted publicity may accompany sexual harassment charges, having an immeasurable impact on an organisation's ability to attract and retain valued employees. Other indirect costs may include lower productivity, lower quality, increased absenteeism, and increased sick leave costs (Gutek et al., 1990; Koss, 1990). Thus sexual harassment must be addressed and eliminate not only because it is a violation of the rights of an individual, but because it also affects the morale and image of the workplace.

\section{The Malaysian Scenario}

Sexual behavior in the workplace is not a recent phenomenon. While evidence of this type of behavior could be traced throughout the history of the nation, sexual harassment remain a silent or hidden social issue until the mid 1990's. Today, as a response to women's movements and also the government's effort, the issue of sexual harassment has found its place in the Sixth and Seventh Malaysia Plan. Under the Ministry of National Unity and Social Development, a National Action Plan has been drawn up to conduct training and awareness programmes to help women understand the issue of sexual harassment. Thus the concept of sexual harassment in Malaysia is of recent origin.

Badriyah (1988) who studies sexual harassment in 'large organisations' in Penang revealed that approximately $80 \%$ of the women are sexually threatened at work. Meanwhile according to the Human Resources Ministry there are only 110 known cases of sexual harassment reported by the victims between 1997-1999. These cases reported to the ministry involved male superiors as the offenders. 
The Malaysian Trade Union Congress (MTUC) has conducted a survey with public sector employees on sexual harassment but unfortunately has not been able to sustain follow up actions on the issue. This is partly because in Malaysian organizational settings, sexual harassment issues are seldom discussed in the open. Though sexual harassment occurs at many levels of organization, many of the incidents have been pushed aside due to differences in definitions and understandings.

Although in other countries studies show that sexual harassment is a common phenomenon in the workplace, data from the Women Crisis Center (WCC) shows otherwise, (Table 1). The reported cases might only reflect the 'tip of the iceberg'. Most of the cases were either solved internally or the victim quits her job. Among the reasons is that while rape and other domestic violence are recognized as blatant and outright forms of violence against women, sexual harassment has yet to be acknowledged as a violation because of its more insidious nature. What makes it harder to address is that, it is considered to be 'acceptable' or that it is normal for men to sexually harass and it is taboo for women to confront it. The fear of being blamed for sexual harassment and that they somehow are deemed to have 'asked' to be harassed, prevents many women from speaking up and speaking out against it.

Table 1

Sexual Harassment Cases at the Workplace

\begin{tabular}{|l|c|c|c|c|c|c|c|c|c|c|c|}
\hline Year & 1986 & 1987 & 1988 & 1989 & 1990 & 1991 & 1992 & 1993 & 1994 & 1995 & 1996 \\
\hline $\begin{array}{l}\text { Sexual } \\
\text { Harassment }\end{array}$ & 2 & 1 & 1 & 4 & 0 & 2 & 0 & 1 & 2 & 1 & 1 \\
\hline
\end{tabular}

Source: Jelita, August, 1997

Policy making and guidelines regarding proper behaviour at work, are still quite ambiguously put in the Malaysian General Order. The General Order only briefly states that no public officers should conduct himself in such a manner as to bring the civil service into disrepute or to bring discredit thereto (Peraturanperaturan Pegawai Awam, 1993). Since the code of conduct was enacted in 1993 only one public employee has been taken to task.

According to AWAM (Malay Mail, 5 December, 1995: 4) the closest thing to legal protection is found under section 509 of the Penal Code which states that anyone who insults the modesty of any woman by word, through sound, gesture or object, intentionally if convicted, is liable to a jail term up to one year and/or be fined. And when it involves assault or use of criminal force, the aggressor may be charged under section 354 of the Penal Code carrying a maximum jail term of up to two years or whipping or a fine or any two of such punishment.

The irony is that, generally according to Mansor ${ }^{1}$, the Head of Sexual Assault of Bukit Aman Police Headquarters, they do not act on cases of this nature unless physical injuries have been inflicted. Although such laws exist, it is difficult to prove sexual harassment in court as they often take place in close and private settings and few are willing to testify as witnesses (interview). The victims are often traumatized by their experience and end up in suffering. Victims who are mainly women seemed to be reluctant to make complaints as they are afraid that they will labeled as trouble maker instead. Apart from this, there are also victims who are not aware that they have been sexually harassed. 

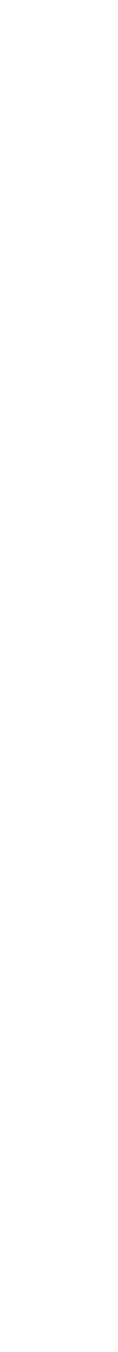

Thus this creates a need for employees to go beyond the guidelines to fine tune policy procedures as to reflect specific circumstances within the organisation. This is due to the fact that the courts have stated that the policy must be explicit and it must define and give various examples of behaviours that constitute sexual harassment. Explicitness is particularly important for the hostile work environment form of harassment. For example, many employees are probably aware that making promotional decisions contingent on the granting of sexual favors is harassment but they may not recognise that jokes, postures, gesture or computer pornography are also forms of sexual harassment.

The sexual harassment issue in Malaysia started to catch public attention in 1997. A great deal of the new found interest in sexual harassment can be attributed to the uproar created in January, 1997, when Lillian Threra de Costa alleged Jennico Associates Sdn. Bhd. that she was constructively dismissed or forced to resign from her company, due to sexual harassment. The Industrial Court's decision in Jennico Associates Sdn. Bhd. Vs. Lillian was regarded sexual harassment in the workplace as an offence for the first time in Malaysia. In doing so, it affirmed convictions long held by proponents of gender equality that sexual harassment needs to be taken seriously. It was an occasion of much joy for women's groups and those engaged in the fight for social justice in Malaysia. This case was considered a landmark decision in Malaysia's legal history.

A year after the De Costa case in 1998, the Minister of Unity and Social Development emphasised that there should be guidelines on how individuals in organisations should carry out themselves in the workplace, and this sparked efforts to take action on the issue. The Minister said that although sexual harassment was not given due thought in the country, it was time to address the problem because it was present in offices, colleges, universities and public places. The severity of sexual harassment was also not known because of the lack of awareness. Until now only the courts have decided on what sexual harassment is. She appointed members from the government and private agencies, NGOs and higher learning institutions, to study the definition of sexual harassment, how often it occurs and the number of victims subject to it. Fortunately the media played a major role by giving great coverage on this issue.

Later, on the $17^{\text {th }}$ of August 1999, the Ministry of Human Resource launched the Code of Practice on the Prevention and Eradication of Sexual harassment in the Workplace for adoption and implementation by employers of the private sector to deal with the issue. The meaning of sexual harassment according to the code of practice by the Ministry of Human Resource is any unwanted conduct of sexual nature having the effect of verbal, nonverbal, visual, psychological or physical harassment: i) that might, on reasonable grounds, be perceived by the recipient as placing a condition of a sexual nature on her/his employment or ii) that might, on reasonable grounds, be perceived by the recipient as an offence or humiliation, or a threat to her/his well-being, but has no direct link to her/his employment. With the presence of the code of practice, it is hoped that it will begin to give some hope and 'life' to the past and present victims of sexual harassment.

\section{Purpose of the Study}

The objective of the study is to see the perception and incidence pattern of SH among administrators at the workplace. The study also intends to ascertain how $\mathrm{SH}$ is being handled within the organisation.

With these sets of objectives, the study can provide information regarding which behaviors most administrators consider to be sexual harassment, thus establishing areas of consensus in the perception of potentially harassing behaviors. These can pave the way for management to come up with proper whistle blowing (complain mechanisms) and policies towards sexual harassment at work since the definition and legal guidelines are still being developed. 


\section{Why Study Administrators}

Administrators are made the focus of this study because normally they are the ones who are advised to be approached first if there is any form of personnel related problems in the organization. Under the Malaysian Employment Law the employer is responsible for providing a conducive environment or they can be charged in court for not doing so. The prompt investigation of a sexual harassment complaint followed by appropriate action will usually prevent a finding of liability against the employer. Thus the existence of an effective grievance procedure and the enforcement of a sexual harassment policy can help employers avoid liability.

Administrators can influence the social work norm at workplace. Past study (Pryor et al., 1993) has suggested that local social norms are important influence of sexual harassment. Sexual harassment may be more likely to occur in situations where it is perceived as socially permissible (Gutek, 1990; Haavio-Mannila, Kaupinen-Toraopaonen \& Kandolin, 1988). To some extent, the reactions of work group leaders (e.g. management in organizational settings) to sexual harassment may define local social norms. Potential harassers may perceive that they are free to harass if management tolerates or condones such behavior. So, the perceived attitudes of local work group leaders may provide an important index of local norms (Larwood, Szwajkwoski \& Rose, 1988) in the organisation.

In this study sexual harassment is conceptualized as a social behavior some people do some time. For example three studies demonstrated that high "Likelihood to Sexually Harass" (LSH) men behave in a sexually harassing way in certain social situations (Pryor, 1985, Pryor, La Vite \& Stoller,1993; Pryor, Giedd \& Williams, 1995). These studies demonstrated the importance of situational factors in predicting sexual harassment. High LSH men only seemed to act upon their proclivities for sexual harassment when the local social norms condoned or permitted such behavior (Pryor et al., 1995). Their research showed that social norms permitting sexual harassment can also develop in co- hesive groups of peers as well as emanating from authority figures. Thus people's perceptions of social norms are known to be important determinants of a wide variety of social behaviors (Azjen \& Fishbein, 1980).

Hence it is assumed that exposure to a harassing model could influence organizational norms "everybody's doing it and it's okay to do it". This assumption has theoretical roots in Lewin's (1951) analysis that behavior is a function of the social environment and the person. Hence this study will help Malaysians to gather information on how administrators perceive, experience and handle sexual harassment which in turn will give insights on the norms of the public sector administrators towards sexual harassment in the Malaysian context.

Another problem in trying to confront an issue like sexual harassment lies in the difficulty of establishing a comprehensive definition (Arvey \& Cavanaugh, 1995). As harassment would seem to some as a matter of interpretation, there is an inclination to individualize incidents and to blame the victim. By defining sexual harassment and differentiating it from other sorts of workplace behavior, the paranoia of being wrongly accused of the crime can dissipate. Thus a key question in overcoming sexual harassment concerns what particular behaviours are considered to be harassing. Hence if information on perception and how sexual harassment is handled in the organisation is obtained then the guidelines can be adjusted to fit both the employers' and the employees' needs towards curbing sexual harassment in the workplace.

\section{RESEARCH METHODOLOGY}

This is an exploratory research which seeks to understand the perception and incidence pattern of SH by administrators within the Malaysian context. The instrument used in this study is Utara Sexual Harassment Questionnaire (USHPQ) which was initially formulated from a review of the relevant literature and 
adaptation of previous appropriate questionnaires from the west (Soutar et al., 1987; Reese\& Lindenberg, 1997). The items in USHPQ were reviewed and formulated in accordance with the Malaysian context with the help of focus-group-discussions (FGD). These FGDs were made up of public administrators and members from women's organizations.

The USHPQ instrument consists of 44 questions that described the four types of sexual harassment. It consisted of physical, visual, verbal and non-verbal forms of sexual harassment. The types of sexual harassment referred to in this study are based on quid pro $q u o$ - this occurs when a perpetrator requests sexual activity from the victim in exchange for work benefits; and hostile environment - one that occurs when a perpetrator creates an offensive or intimidating environment for the victim.

Respondents were given a "yes" and "no" choice to decide which items are perceived as sexual harassment. They are also to mark similar items that they have faced in the workplace. The study also stated that it only takes into account sexual harassment that occurred within the workplace and which was perpetrated by employees of the opposite sex in the organisation concerned. The number of "yes" choice, identified by respondents on the 44 items will show their perception towards $\mathrm{SH}$.

In deciding what constitutes as sexual harassment behaviour in the questionnaire the study used 2 possible tests as outlined by Fenley (1988). They are i) Would I like someone to behave in this way towards my spouse, sweetheart, or parent? And ii) Would I be embarrassed to see my remarks or behaviour described to my family or reported in the newspaper? These questions act as a benchmark in attaining the working definition of sexual harassment for this study.

There were a total of 545 government departments in Kedah, Kelantan, Perlis and Terengganu. Sixty departments (about $10 \%$ of the total population) were randomly selected from the list of departments furnished by the State Secretary Administration Office from four states. Every administrator from each of the selected departments was taken as sample for this study.

Formal approval from all the heads of department from each of the selected department was obtained before the questionnaires were mailed to them. Some of the departments that did not permit the study to be carried out, were taken out from the sample list, and replaced with other departments through random sampling from the total population. Approximately 1100 questionnaires were mailed to all the public administrators in the 60 departments. A total of 586 administrators responded, for a response rate of approximately $53 \%$.

\section{FINDINGS AND DISCUSSION}

\section{Demographic Background of the Respondents}

About $72 \%$ of the total sample were male and $28 \%$ were female respondents. The female are a minority as administrative jobs are considered traditionally male jobs. $92.7 \%$ of the population comprised of Malays, $5.5 \%$ Chinese, $1.2 \%$ Indian and other races $0.3 \%$. From the sample $88.9 \%$ of the respondent are married, $9.0 \%$ are still single and $2.0 \%$ are widows or widowers. Meanwhile the education level of the administrators varies from High School Certificate holders to University graduates. The sample is made up of $23.5 \%$ administrators with High School Certificates (became administrators through rank and file), $21.0 \%$ has Diplomas and $41.6 \%$ are undergraduates, and $12.8 \%$ are graduates and Ph.D. holders.

\section{Perception Towards Sexual Harassment}

The first objective is to investigate the perception of SH among administrators. This study showed that an act is perceived as harassment by $83.1 \%$ of the respondents when men harass women, and $66 \%$ perceives an act as a harassment if it was done by women to men, and the score was lower when a man does it to a man $(30.4 \%)$ or between women $(29.4 \%)$. 
Specifically, the perception of sexual harassment among administrators varied according to the different categories of the SH. Table 2 contains the percentage of agreement (those who answered "yes" to the ques- tion) that a particular item is perceived as sexually harassing. Touching, kissing, hugs are acts which are perceived by $97 \%$ of respondents as sexually harassing (physical category).

Table 2

Perception on Harassment Items and who Faced Harassment (Ranked high to low)

\begin{tabular}{|c|c|c|}
\hline Item & Item Description & $\begin{array}{l}\text { The percentage of } \\
\text { agreement (yes) that } \\
\text { this item is perceived } \\
\text { as sexually harassing }\end{array}$ \\
\hline 1 & Touching of the intimate parts of the body & 99 \\
\hline 4 & Kisses & 97.1 \\
\hline 5 & Hugs & 96.6 \\
\hline 21 & Demands for favours with threats or mistreatments & 96.6 \\
\hline 29 & Tried to force you physically into having sexual intercourse & 95.9 \\
\hline 30 & Tried to force you verbally into having sexual intercourse & 95.6 \\
\hline 7 & Brushing up against another employee's body & 95.2 \\
\hline 15 & Leering/ogling/cornering & 95.1 \\
\hline 23 & Sexual letters & 94.5 \\
\hline 24 & Sexual telephone calls & 94.5 \\
\hline 22 & Implied reward or better treatment for sexual co-op operation & 93.9 \\
\hline 34 & Making sexually suggestive gestures & 92.5 \\
\hline 20 & Sexual remarks about sexual practices & 92 \\
\hline 17 & $\begin{array}{l}\text { Pinups, displays, circulation, pictures, cartoons, stories or pornography } \\
\text { of sexually suggestive materials }\end{array}$ & 91 \\
\hline 19 & Sexual remarks about the body & 91 \\
\hline 14 & Staring or excessive eye contact or suggestive looks & 98.6 \\
\hline 16 & Sexual jokes, stories or language & 88.2 \\
\hline 26 & $\begin{array}{l}\text { Sexually suggestive displays of pictures, break time games in the } \\
\text { computer }\end{array}$ & 88.1 \\
\hline 37 & Offensive sexual remarks about self to others & 87.4 \\
\hline 40 & Target of sexual innuendos & 85.7 \\
\hline 38 & Co-worker spreading sexual rumors about yourself to others & 85 \\
\hline 28 & Making reference to your sex life and personal life & 83.8 \\
\hline 18 & Sexual remarks about cloth & 83.4 \\
\hline 39 & $\begin{array}{l}\text { Making it necessary to respond positively to sexual or social invitations } \\
\text { in order to be well-treated }\end{array}$ & 83.4 \\
\hline 8 & Standing close to you in a way that makes you uncomfortable & 82.9 \\
\hline 25 & Whistling and making cat calls (making sounds) & 82.3 \\
\hline 6 & Pinching & 81.2 \\
\hline
\end{tabular}




\begin{tabular}{|c|l|c|}
\hline Item & Item Description & $\begin{array}{l}\text { The percentage of } \\
\text { agreement (yes) that } \\
\text { this item is perceived } \\
\text { as sexually harassing }\end{array}$ \\
\hline 27 & $\begin{array}{l}\text { Not dressed according to the normal dress code as stated by the organiza- } \\
\text { tion or out of the norm }\end{array}$ & 79.2 \\
\hline 12 & $\begin{array}{l}\text { Asking to stay late and working late with him/her when there is no work to } \\
\text { do }\end{array}$ & 79.0 \\
\hline 13 & Giving intimate gifts for example perfume, lingerie and the like. & 76.5 \\
\hline 2 & Touching of the non-intimate parts of the body or hand, etc. & 75.9 \\
\hline 41 & Using words in a patronizing way, for example, "sexy", "sweetie", "darling" & 75.9 \\
\hline 3 & Patting & 73.5 \\
\hline 35 & $\begin{array}{l}\text { Telling jokes or having conversations about women which you found } \\
\text { offensive to women }\end{array}$ & 72.2 \\
\hline 36 & $\begin{array}{l}\text { Telling jokes or having conversations about men which you found offensive } \\
\text { to women }\end{array}$ & 68.3 \\
\hline 9 & Acting in over familiar behavior & 67.9 \\
\hline 31 & $\begin{array}{l}\text { Treating differently because you are a woman/man, mistreating, slighting or } \\
\text { ignoring. }\end{array}$ & 66.7 \\
\hline 11 & Pressuring for dates for example drinks, dinners etc. & 63.8 \\
\hline 42 & $\begin{array}{l}\text { One employee alleging another employee got a raise, promotion or better } \\
\text { job assignment because the other woman/man and the boss were intimate }\end{array}$ & 61.6 \\
\hline 32 & $\begin{array}{l}\text { Sexist remarks or putting you down because of your sex, e.g., suggesting } \\
\text { that women or men are too emotional or chauvinist }\end{array}$ \\
\hline 33 & Subjecting someone to insults or ridicule because of their sex & 59.9 \\
\hline 44 & An employee commenting on her moral & 56.7 \\
\hline 10 & Commenting on appearances & $\begin{array}{l}\text { Male co-worker refusing to listen to her work-related ideas or suggestions } \\
\text { seriously }\end{array}$ \\
\hline 43 & . & \\
\hline
\end{tabular}

$\mathrm{N}=586, \mathrm{KR}-20=0.9441$

The difference of perception between male and female respondents were also investigated and the results are as depicted in Table 3. Sexual bribery, explicit propositions, and physical sexual advances were perceived by almost everyone as sexual harassment. On the other hand, behaviors such as sexist comments, undue attention, coarse language, and jokes were much less likely perceived as harassment. For example $99 \%$ of the subjects viewed touching of private parts as sexual harassment, whereas coarse language and jokes scored lower as harassment items. Fewer individuals (62\%-47\%) defined stereotyped or gender focussed items (refer to
Table 2, and items 33, 43 and, 44 in USHPQ questionnaire) as harassment. Indeed, Fitzgerald \& HessonMcInnis (1989) concluded from their multidimensionalscaling analysis that gender harassment may be conceptually different from sexual harassment, and Tata's (1993) experiment highlighted the ambiguity in interpreting gender harassment. Stockdale and Vaux (1993) have offered the possible explanation that gender harassment may not be perceived as sexual harassment because it involves behaviors that are socially acceptable and widely displayed. 
Table 3

Difference in Perception between Men and Women who have Faced Harassment

\begin{tabular}{|c|c|c|c|}
\hline Item & Item Description & Men & Women \\
\hline Item 1 & Body Private & 98.9 & 98.7 \\
\hline Item 2 & Body N. Private & 82.5 & 92.2 \\
\hline Item 3 & Patting & 82 & 90.9 \\
\hline Item 4 & Kisses & 97.8 & 98.7 \\
\hline Item 5 & Hugs & 97.8 & 98.7 \\
\hline Item 6 & Pinching & 83.1 & 89.6 \\
\hline Item 7 & Brushing & 96.2 & 97.4 \\
\hline Item 8 & Standing Close & 88.5 & 90.9 \\
\hline Item 9 & Over Familiar & 78.7 & 83.1 \\
\hline Item 10 & Comments on Appearance & 65.6 & 68.8 \\
\hline Item 11 & Dates & 71.6 & 77.9 \\
\hline Item 12 & Staying Late & 79.2 & 90.9 \\
\hline Item 13 & Intimate & 79.2 & 84.4 \\
\hline Item 14 & Suggestive Looks & 90.7 & 94.8 \\
\hline Item 15 & Ogling & 95.1 & 93.5 \\
\hline Item 16 & Sexual Jokes & 91.8 & 93.5 \\
\hline Item 17 & Pinups & 94 & 93.5 \\
\hline Item 18 & Cloth & 88 & 93.5 \\
\hline Item 19 & Body & 92.9 & 94.8 \\
\hline Item 20 & Sexual Practices & 93.4 & 96.1 \\
\hline Item 21 & Demands & 62.3 & 70.1 \\
\hline Item 22 & Sexual Co-op & 95.1 & 96.1 \\
\hline Item 23 & Letters & 94.5 & 97.4 \\
\hline Item 24 & Telephone & 95.6 & 97.4 \\
\hline Item 25 & Whistling & 81.4 & 93.5 \\
\hline Item 26 & Computer & 89.1 & 94.8 \\
\hline Item 27 & Dress Code & 88 & 87.0 \\
\hline Item 28 & Sex Life & 85.2 & 89.6 \\
\hline Item 29 & Sexual Intercourse & 95.1 & 92.2 \\
\hline Item 30 & Sexual Intercourse-verbally & 94.5 & 93.5 \\
\hline Item 31 & Treated Differently & 69.9 & 76.2 \\
\hline Item 32 & Put Down & 66.7 & 79.2 \\
\hline Item 33 & Ridicule & 63.4 & 76.6 \\
\hline Item 34 & Sex. Gestures & 91.3 & 93.5 \\
\hline Item 35 & Offensive to Women & 78.1 & 87.0 \\
\hline Item 36 & Conversations about Men & 73.2 & 84.4 \\
\hline Item 37 & Sex. Remarks & 90.7 & 90.9 \\
\hline Item 38 & Sexual Rumours & 84.2 & 94.8 \\
\hline Item 39 & Sexual Invitations & 83.6 & 89.6 \\
\hline Item 40 & Sexual Innuendoes & 86.9 & 93.5 \\
\hline Item 41 & Sex Words & 83.6 & 81.8 \\
\hline Item 42 & Promotion Intimate & 68.3 & 77.9 \\
\hline Item 43 & Work-related Ideas & 57.4 & 68.8 \\
\hline Item 44 & Moral & 65.6 & 74.0 \\
\hline
\end{tabular}


The results in Table 3 also shows that there were very small differences in the perception of SH. These are also found in various other studies (Gutek, 1982; Gutek et al., 1990). However, overall, women administrators perceived each behavior as more harassing compared to their male counterparts. Analysis on the differences in perception between men and women who have been harassed and not harassed indicated that respondents, be it women or men, who have been harassed tend to perceive the items more harassing than those who have not faced SH. Analysis on the comparison between women and men who have been harassed showed that women who have been harassed, more frequently perceived items as $\mathrm{SH}$ than men who have been harassed.

Stockdale \& Vaux, (1993) indicate that the tendency to misperceive friendly for sexual behaviour among men appears to be linked to a constellation of other beliefs, including traditional sex role attitudes, tolerance for sexual harassment, and beliefs that women express sexual interest by being friendly.

\section{Incidence Pattern of Sexual Harassment}

The second objective is to ascertain the pattern incidence of SH among public administrators. Results indicated that $43.9 \%$ has experienced at least one form of the sexual harassment items as described in the questionnaire. Whereby $47 \%$ of the total women administrators and approximately $43 \%$ of the men administrators have faced sexual harassment at work (Figure 1).

In terms of race it happens at the same rate across all races (Figure 2). Hence the occurrence of sexual harassment is not gender or race specific as has been assumed before.

Meanwhile, in terms of occurrence, the respondents were asked if they had experienced harassment by a specific act as outlined in the USHPQ. In general it was observed that the respondents faces the less severe act more frequently compared to the more severe form of sexual harassment (Table 4). As the sexual harassment items decreased in severity in each category, so did the percentage of administrators perceiving it to constitute as sexual harassment behavior.

\section{Figure 1}

Incidence of Sexual Harassment by Gender

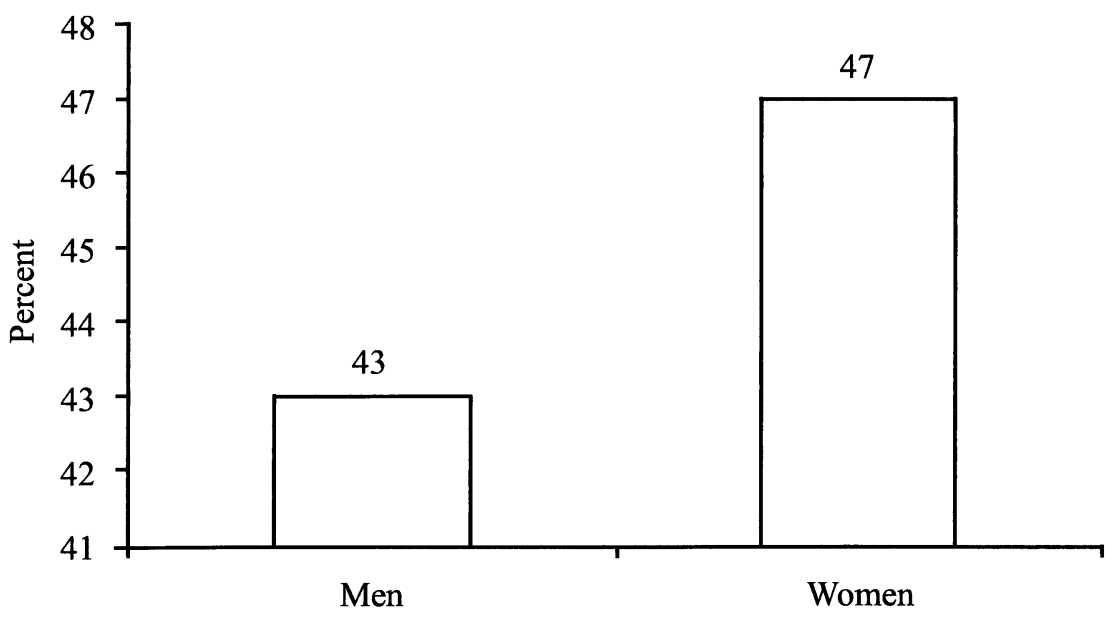


Figure 2

Incidence of Sexual Harassment According to Race

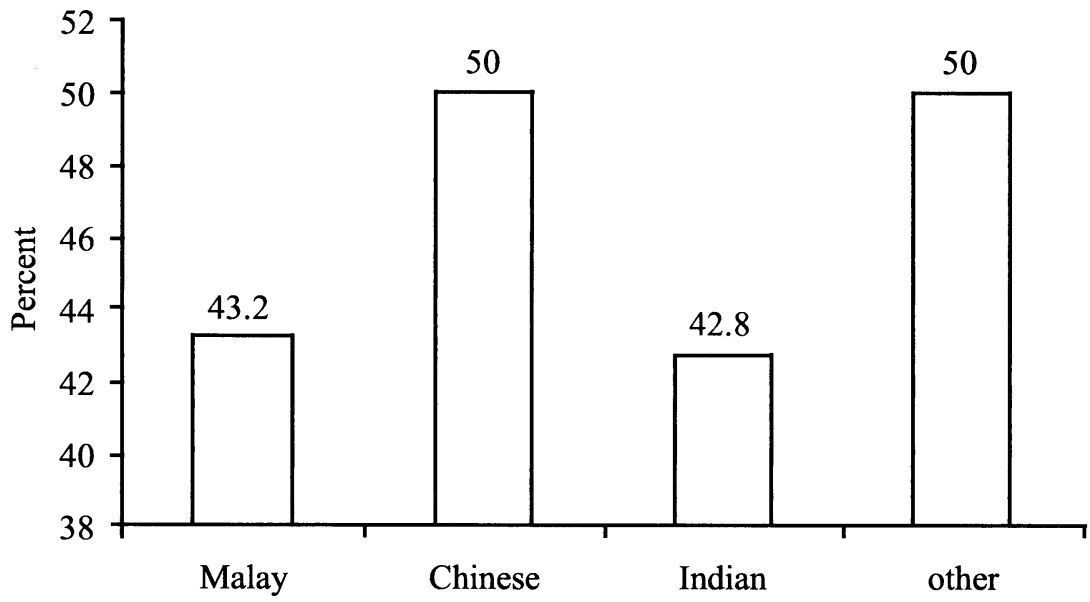

Table 4

SH Items By Victims in Descending Order

\begin{tabular}{|l|l|c|c|}
\hline \multirow{2}{*}{ Item } & \multirow{2}{*}{ Item Description } & \multicolumn{2}{|c|}{$\begin{array}{c}\text { Respondents admitted being } \\
\text { harassed by this act }\end{array}$} \\
\cline { 3 - 4 } & & $\%$ & Frequency \\
\hline 41 & Sex words & 83.1 & 216 \\
\hline 12 & Staying late & 82.7 & 215 \\
\hline 8 & Standing close & 42.3 & 110 \\
\hline 2 & Body (private) & 42.3 & 110 \\
\hline 3 & Patting & 34.6 & 90 \\
\hline 10 & Comment on appearances & 33.5 & 87 \\
\hline 16 & Sexual jokes & 31.2 & 81 \\
\hline 9 & Over familiar & 31.2 & 81 \\
\hline 11 & Date & 29.6 & 77 \\
\hline 44 & Moral & 23.5 & 61 \\
\hline 35 & Offensive to women & 23.1 & 60 \\
\hline 14 & Suggestive looks & 22.3 & 58 \\
\hline 36 & Conversation about men & 21.9 & 57 \\
\hline 6 & Pinching & 20.0 & 52 \\
\hline 43 & Work-related ideas & 18.5 & 48 \\
\hline 19 & Body verbal & 18.1 & 47 \\
\hline 32 & Put down & 16.5 & 43 \\
\hline 18 & Cloth verbal & 16.2 & 42 \\
\hline 31 & Treated differently & 15.0 & 39 \\
\hline 17 & Pinups & 14.6 & 38 \\
\hline 13 & Intimate gifts & 14.2 & 37 \\
\hline 27 & Dress code & 13.5 & 35 \\
\hline 33 & Ridicule & 11.5 & 30 \\
\hline 24 & Telephone & 11.2 & 29 \\
\hline 7 & Brushing & 10.8 & 28 \\
\hline
\end{tabular}




\begin{tabular}{|l|l|r|c|}
\hline \multirow{2}{*}{ Item Item Description } & \multicolumn{2}{|c|}{$\begin{array}{c}\text { Respondents admitted being } \\
\text { harassed by this act }\end{array}$} \\
\cline { 3 - 4 } & & $\%$ & Frequency \\
\hline 20 & Sexual practices verbal & 10.4 & 27 \\
\hline 15 & Ogling & 10.0 & 26 \\
\hline 21 & Demands & 9.2 & 24 \\
\hline 25 & Whistling & 8.1 & 21 \\
\hline 40 & Sexual innuendoes & 7.7 & 20 \\
\hline 38 & Sexual Rumours & 7.7 & 20 \\
\hline 42 & Promotion intimate & 7.7 & 20 \\
\hline 34 & Sexual gestures & 6.9 & 18 \\
\hline 37 & Sex. Remarks & 6.5 & 17 \\
\hline 5 & Hugs & 6.2 & 16 \\
\hline 28 & Sex life & 6.2 & 16 \\
\hline 26 & Computer & 5.4 & 14 \\
\hline 1 & Body Private & 3.8 & 10 \\
\hline 23 & Letters & 3.5 & 9 \\
\hline 22 & Sexual Co-op & 2.3 & 6 \\
\hline 4 & Kisses & 1.9 & 5 \\
\hline 30 & Sexual intercourse-verbal & 1.9 & 5 \\
\hline 39 & Sexual invitations & 1.5 & 4 \\
\hline 29 & Sexual intercourse & 1.2 & 3 \\
\hline & & & \\
\hline
\end{tabular}

\section{How Sexual Harassment Is Managed}

The final objective of the study is to ascertain how $\mathrm{SH}$ is managed in the organization. Interestingly, it was found that almost $90 \%$ of the administrators in this study agreed that it is important to have an anti-harassment act in their organisation. On the other hand, almost $90 \%$ of respondents in the study either do not know or were not sure whether there were procedures in their organisation to manage sexual harassment complaints.

Almost $90 \%$ of the administrators admitted that they themselves were not sure of the reporting procedures even if it happened to them. When it happened they frequently confronted the harassers in a nice way (59.4\%), followed by lodging a complaint $(30.5 \%)$ and the last resort was to ignore the incidence $(10.1 \%)$. Studies in the past showed that target of sexual harassment use avoidance/denial, low intervention strategies more frequently than other strategies and that these strategies are the least effective in ending sexual harassment behavior (Knapp, Faley \& Dubois, 1997).
This study also showed that $64.2 \%$ of the administrators have little or no confidence at all that they would be safe or be protected by the organisation when lodging a complaint. The administrators faced several consequences if they reported the incidents. Among them were that the reprisal was still pending (69.2\%), it would got them into more trouble (46.2\%), no action was taken (38.5\%), top management was not happy for making such report, so were the supervisors (30.8\%) and co-workers (61.5\%). These results showed that it created a very uncomfortable atmosphere for the individuals who made complaints reagarding sexual harassment. Other studies (Fitzgerald \& Shullman, 1993; Spann, 1990) also showed that a victim's reluctance to report sexual harassment may be exacerbated by the attitudes and behaviors of executives and managers. If sexual harassment is tolerated by management and if reports are not taken seriously, targets may believe that the risks of reporting are too great. 
The findings of the study also showed that although the respondents have been harassed, yet $15.8 \%$ said that SH does not happen in their organisation. This is an important finding given that other studies have also found that victims who reported experiencing various behaviours did not feel that they have been harassed (Fitzgerald et al., 1988). Their lack of awareness of what constitutes, as sexual harassment behaviour at workplace is the main reason that $\mathrm{SH}$ is seldom discussed in the work settings. This might pose a problem to victim who approaches such administrators that have little awareness on the issue (Brooks \& , 1991). As Knapp et al., (1997) concluded in her study that the perceived attitude of those at the top of the organizational hierarchy may influence the organizational climate regarding sexual harassment. If sexual harassment is viewed as a legitimate workplace issue by members of top management, the risks of confrontation may be less (Spann, 1990).

Other research (Savery, et al., 1985;) also pointed out that many human relation managers did not see harassment as a problem in their companies because it was not reported. Accordingly in this study, there are administrators (7.8\%) who still consider that it is not important to have an anti-sexual harassment Act in their organization. This might add problems to organizations in trying to ameliorate SH cases at the organizational level. This view is similar to findings in Knapp's study (1997) which demonstrated that as individuals become informed about the policy, they are more likely to use it. On the other hand, if individuals are uncertain about the reporting process, they may be less likely to employ it as a coping action.

\section{CONCLUSION}

In general, the study finds that out of the 44 items listed in the USHPQ, items which are related to the physical and verbal categories are most often perceived as sexually harassing. There are small differences between gender in terms of perception. Further, administrators that have been victimized before tend to perceive a behavior as harassment compared to non victims. And women victims had a higher tendency to perceive an act as sexual harassment compared to men who have been victimized. In terms of occurrence administrators face behaviors that is related to hostile work environment and less of the quid pro quo type. Results also showed that it is an irony that although a majority of them favour anti-sexual harassment act in their organization, $90 \%$ of them are not sure or do not know if such procedures exist in their organisation. In fact some of those who reported faced retaliation and many of them did not lodge report because they were afraid of such consequences.

\section{RECOMMENDATION}

These recommendations were outlined with specific reference made to the high level of perception towards $\mathrm{SH}$ amongst administrators and the present practice in public organizations to curb the incidence of $\mathrm{SH}$ at the work place. The first role to be taken by management is that of role model; demonstrating recognition of the value of the employee's dignity, the importance of his/ her professional contribution to the company, leading by example. Management should demonstrate an attitude of respect towards other men and women within the organization, where opinions of both are valued, and where opportunities for advancement are equally available and determined solely on professional merit. In this way, the administrators can model expected behavior to his/her subordinates and this modeling can in turn be disseminated throughout the ranks.

The second role for management lies on the establishment and enforcement of a sexual harassment policy. This is because $90 \%$ of the respondents are not sure how their organizations manage SH complaints. This policy should be a vehicle for educating all company members, regardless of position or gender, of company expectations regarding the sexual harassment issue. It can also be a tool in helping to foster an environment 
of respect between all employees. The policy should outline complaint procedure including the assurance that management will take serious action investigating complaints, and disciplinary procedures for those found guilty of sexual harassment. This sexual harassment policy will also serve as a means of defense for companies who are faced with a lawsuit over sexual harassment charges. With any sexual harassment policy that is formulated within an organization, emphasis should be placed on prevention whereby the costs to an organization are much less if an environment of sexual harassment can be avoided.

Since the study found that the incidence of sexual harassment on some categories is quite significant, it is therefore necessary for employers and unions to take proactive measures to deal with the problem and ensure a safe and healthy working environment for all. The code of practice on the preventing and handling of sexual harassment should aim to provide the in house preventive and redress mechanisms for dealing with the problems at the company level without having to seek redress through other channels such as the Industrial Court, to save costs, time, and to avoid embarrassment.

Last but not least employees cannot rely on the societal consciousness of individual managers, faced with conflicting priorities, to meet their needs for a safe and respectful work environment. For management, sexual harassment must remain an issue enmeshed with employee effectiveness, and seen as threat not only to the individuals who suffer most personally from it but also to the most fundamental resource of the company - the personnel resource.

\section{BIBLIOGRAPHY}

Arvey, R. (1987). Accurate survey methodology is crucial in detecting sexual harassment. Minnesota Management Review, 17, 27.
Arvey, R.D., \& Cavanaugh, M.A. (1995). Using surveys to assess the prevalence of sexual harassment: Some methodological problem. Journal of Social Issues, 51, 39-52.

Azjen, I., \& Fishbein, M. (1980). Understanding Attitudes and Predicting Social Behavior. Englewood Cliffs, NJ: Prentice Hall.

Badriyah, S. (1988). Kejadian gangguan seksual di dalam Kampus USM. Kajian Jangka Pendek, USM, Pulau Pinang.

Baker, D.D., Terpestra, D.E., \& Larntz, J. (1990). The influence of individual characteristics and severity of increasing behavior on reactions to sexual harassment. Sex Roles, 22, 305-325.

Bargh, J.A., \& Pietromonaco, P. (1982). Automatic information processing and social perception. The influence of trait information presented outside of conscious awareness on impression formation. Journal of Personality and Social Psychology, 43, 437-449.

Bem, S.L. (1981). Gender schema theory: A cognitive account of sex-typing. Psychological Review, $88,354-364$.

Bennett-Alexander D.D., \& Pincus L.B. (1995). Employment Law for Business. Chicago IL: Richard D. Irwin.

Bingham, S.G., \& Schere, L.C. (1993). Factors associated with responses to sexual harassment and satifaction with outcome. Sex Roles, 29, 239269.

Brooks, L., \& Perot, A.R. (1991). Reporting sexual harassment: Exploring a predictive model. Psychology of Women Quarterly, 15, 31-57. 
Burke, N.R. (1995). Incidence consequences of sexual harassment in a professional services firm. Employee Counseling Today, 7(3),19-23.

Collins, E.G.C., \& Blodgett, T.B. (1981). Sexual Harassment: Some see it.... Some Won't. Harvard Business Review, 59(2), (MarchApril): 76-95.

Crain, A.K. (1995). Implementing business ethics: Sexual harassment. Journal of Business Ethics, 14, 299-308.

Dozier, J.B., \& Miceli, M.P. (1985). Potential predictors of whistle blowing: A proposal behaviour perspective. Academy of Management Review, 10, 823-836.

Fenley, T. (1988). Dealing with Sexual Harassment: American Experience Equal Employment Opportunity International, 7(3), 30-33.

Fiske, S.T. (1993). Controlling other people: The impact of power on stereotyping. American Psychologist , 48, 621-628.

Fitzgerald, L.F., \& Shullman, S.L. (1993). Sexual harassment: A research analysis and agenda for the 1990's. Journal of Vocational Education, $42,5-27$.

Fitzgerald, L.R., \& Omerod, A.J. (1991). Perceptions of sexual harassment. Psychology of Women Quarterly, 15, 281- 294.

Fitzgerald, L., Shullman, S., Bailey, N., Richards, M., Swecker, J., Gold, Y., Omerod, M., \& Weizman, L. (1988). The incidence and dimensions of sexual harassment in academic and the workplace. Journal of Vocational Behaviour, 32, 152-175.
Fitzgerald, L.F., \& Hesson-McInnis, M. ( 1989). The dimensions of sexual harassment: A structural analysis. Journal of Vocational Behavior, 35, 309-326.

Garvey, S.M. (1986). Labor relations: The high cost of sexual harassment suits. Personnel Journal, January, 75-84.

Glamour (1979). How working women feel now, about jobs, men, salaries. Glamour, February, 149.

Gutek, B., \& O'Connor, M. (1995). The empirical basis of the reasonable woman standard. Journal of Social Issues, 51, 151-166.

Gutek, B.A. (1985). Sex and the Workplace. San Francisco: Jossey-Bass.

Gutek, B.A., \& Morasch, B. (1982). Sex-rations, sexrole spillover and sexual harassment of women at work. Journal of Social Issues, 38(4), 5574.

Gutek, B.A., Cohen, A.G., \& Konrad, A.M. (1990). Predicting social - sexual behaviour at work: A contact hypothesis. Academy of Management Journal, 33, 560-577.

Gutek, B., Stromberg, R.L., \& Larwood, E. (Eds.). Year Women and Work. Beverly Hills, CA : Sage.

Gutek, B. (1981). Sex and the Workplace: The Impact of Sexual Behaviour and Harassment on Women, Man and Organizations. San Francisco. LA: Jossey-Bass.

Haavio-Mannila, E., Kaupinen-Toropainen, K., \& Kandolin, I. (1988). The effect of sex - composition of the workplace on friendship, romance and sex at work. In B. A. Gutek, A. H. 
Stromberg, \& L. Larwood (Eds.). Women and Work, 3, 123-138. Beverly Hills, CA: Sage.

Hotelling, K. (1991). Sexual harassment: A problem shielded by silence. Journal of Counseling and Development, 69, 497-501.

Kementerian Perpaduan Negara \& Pembangunan Masyarakat (Dis, 1998). Laporan situasi: Bengkel mengenai strategi untuk peningkatan kesedaran dan pencegahan gangguan seksual. Anjuran Kementerian Perpaduan Negara dan Pembangunan Masyarakat, Kuala Lumpur.

Kementerian Sumber Manusia (1999). Kod Amalan untuk mencegah dan membasmi gangguan seksual di tempat kerja.

Knapp, D.E., Faley, R.H., \& Dubois, C.L. ( 1997). Determinants of target responses to sexual harassment: A conceptual framework. Academy of Management Review, 22(3), 687-729.

Koss, M.P. (1990). Changed lives: The psychological impact of sexual harassment. Personnel Psychology.

Larwood, L., Szwajkowski, E., \& Rose, S. (1988). Sex and race discrimination resulting from management-client relationships: Rational bias theory of management discrimination. Sex Roles, 18, 9-29.

Lewin, K. (1951). Field Theory in Social Science: Selected Theoretical Papers. New York: Harper \& Brothers.

Lublin, J.S. (1991). Stopping sexual harassment before it begins. Management Review, April.
MacKinnon C. (1979). A sexual harassment of working woman. A Case of Sex Discrimination. New Haven: C. T. Yale University Press.

MacKinnon, C. (1979). Sexual Harassment of Working Women. New Haven: Yale University Press.

Malay Mail. 5 December 1995, 4-1.

Mingguan Malaysia. 7 September 1997, 25-2.

Peraturan-peraturan Pegawai Awam (Kelakuan dan Tatatertib) 1993, P.U. (A) 395/1993.

Pryor, J.B. (1985). The lay person understands on sexual harassment. Sex Roles. 13, 273-286.

Pryor, J.B., La Vite, C., \& Stroller, L. (1993). A social psychological analysis of sexual harassment: The person/situation interaction. Journal of Vocational Behaviour, 42, 68-83.

Pryor, J., Giedd, J., \& Williams, K. ( 1995). A social pscyhological model for predicting sexual harassment . Journal of Social Issues, 51, 6984.

Reese, L.A., \& Lindenberg, K.E. (1997). Victimhood and the Implementation of Sexual Harassment Policy.

Remick, H., Salisbury, J., Stringer, D., \& Ginorio, B.A. (1990). Investigation of Sexual Harassment Complaints. Women's Studies Quarterly, 8, 207-213.

Savery, G.N., Savery, L.K., \& Dufty, N.F. (1987). Sexual harassment in banking industry: Some Australian evidence. Human Resource Management Australia, 25(30), 82-88. 
Savery, L.K., \& Gledhill, A.C. (1988). Sexual harassby co-workers: Some Australian evidence. Personnel Review, 17, (6): 34-38.

Savery, L.K. (1985). Policies to combat sexual harassment. Human Resource Management Australia. 23(3), 59-61.

Sheffey, S., \& Tindale, R.S. (1992). Perceptions of sexual harassment in the workplace. Journal of Applied Social Psychology, 22, 1502-1520.

Soutar, G.N., Savery, L.K., \& Dufty, N.F. (1987). Sexual harassment in the banking industry: Some Australian evidence. Human Resource Management Australia, 25(3), 82-88.

Spann, J. (1990). Dealing effectively with sexual harassment: Some practical lessons from one city's experience. Public Personnel Management, 19(1), 53-69.

Spence, J.T., Helmreich, R., \& Stapp, J. (1973). A short version of the attitudes toward women scale (AWS). Bulletin of the Psychonomic Society, 2, 219-220.

Stockdale, M.S., \& Vaux, A. (1993). What sexual harassment experiences lead respondents to acknowledge being sexually harassed? A secondary analysis of a university survey. Journal of Vocational Behaviour.

Tangri, S., Martha, S., Burt, R., \& Leanor, B.J. (1982). Sexual harassment at work. Three explanatory models. Journal of Social Issues, 38(4), 3354.

Tata, J. (1993). The structure and phenomenon of sexual harassment: Impact of category of sexually harassing behavior, gender, and hierarchical level. Journal of Applied Social Psychology, 23 (3), $199-211$.

Terpestra, D., \& Baker, D.D. (1986). A framework for the study of sexual harassment. Basic and Applied Social Psychology, 7, 17-34.

Terpestra, D.E. (1989). Who gets sexually harassed? Personnel Administrator, 34, March : 84-88.

Terpestra, D.E., \& Cook, S.E. (1985). Complainant characteristics and reported behaviours and consequences associated with formal sexual harassment charges. Personnel Psychology, 559-573.

Terpestra, O.E., \& Baker, D.D. (1987). A hierarchy of sexual harassment. The Journal of Psychology, 121, $599-608$.

Thacker, R.A., \& Gohmann, S. (1993). Male/female differences in perceptions and effects of hostile environment sexual harassment: Reasonable assumptions? Public Personnel Management, 22(3), Fall: 461-472.

Thacker, R.A. (1994). Innovative steps to take in sexual harassment prevention. Business Horizons, Jan-Feb: 29.

Vaux, A. (1993). Paradigmatic assumptions in sexual harassment research: Being guided without being misled. Journal of Vocational Behavior, 42(1), 116-135.

Washer, L. (1992). 6 steps to stopping harassment. Working Woman, June 51: 78.

Weeks, F., Boles, J., \& Garbin, A. (1986). The transformation of sexual harassment from a private trouble into a public issue. Journal of Social Inquiry, 56, 432-455. 